\title{
Study on Project-driven Teaching Reform of SCM Curriculum
}

\author{
Yourong Chen ${ }^{\mathrm{a}}{ }^{*}$, Juhua Cheng ${ }^{\mathrm{b}}$, Banteng Liu $^{\mathrm{c}}$ and Zhangquan Wang ${ }^{\mathrm{d}}$ \\ Information Science and Technology College, Zhejiang Shuren University, Hangzhou 310015, China

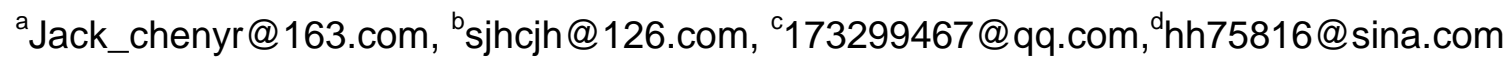

Keywords: SCM curriculum; Project-driven; Tteaching reform; Project groups; Student evaluation

\begin{abstract}
To develop the application-oriented talents in single chip microcomputer (SCM) and embedded directions for students of private undergraduate colleges, project-driven teaching reform of SCM curriculum are studied. Based on homemade SCM experiment box which is composed of basic experiment board, advanced experiment board, perpetual calendar comprehensive experiment board, wireless communication comprehensive experiment board and power board, layered and progressive project groups of SCM are constructed. Project-driven teaching method is proposed. It has nine steps which are project selection, project analysis, knowledge point extraction, task arrangement, knowledge point application, plan formulation, project implementation, project conclusion, thought and improvement. Project teaching evaluation and curriculum assessment mechanism for practical ability are proposed. The evaluation method of student learning scores which pay attention to the teaching process is given. The teaching reform of the curriculum highlights the application, improves the enthusiasm and self-learning ability of students, and improves the teaching efficiency. It has some reference value.
\end{abstract}

\section{Introduction}

In the long-term education reform and development planning framework (2010-2020) [1] and long-term talent development planning framework (2010-2020) of China [2], China will vigorously promote to develop the excellent engineers which have the ability to solve practical problems. In the application-oriented undergraduate colleges, the traditional teaching system and teaching methods are inevitably challenged. Some curriculums need reform. In the specialties of Zhejiang Shuren University such as electronic information engineering and communication engineering, the SCM curriculum generally is the main curriculum in those specialties. It plays an important role in training the SCM engineering design ability, engineering application ability, engineering thinking and problem-solving ability. It also lays a good foundation for the student training in embedded direction. Therefore, it is an important curriculum which requires strong practical ability [3].

In abroad similar curriculums, because the tutorial content is novel, too fragmented and not easy to see the main line, they are not suitable for the student training in private undergraduate colleges. In domestic similar curriculums, curriculums in some schools focus on teaching theoretical knowledge. The theoretical teaching and experiment teaching in time and space are separated. Obviously the teaching method is not suitable for students in private undergraduate colleges [4-5]. Curriculums in some schools focus on the case teaching with Protues software simulation [6]. But they ignore the complexity of hardware circuit. For example, power, crystal and other components can not be simulated in the Protues software. The program which works well in the software simulation sometimes does not work in the hardware. The teaching content which emphasizes the software simulation doesn't really train the debugging ability of actual hardware circuit and the application talent needed in the companies. Thus the curriculum reform group has been studying on the SCM teaching reform. But there are still some problems in the actual teaching process. 
1. Compared with students in some domestic famous universities, the overall quality of students in private undergraduate colleges still has some gaps. Their self-learning and self-discipline abilities are much poorer. It needs to further stimulate the student interest and train the self-learning ability.

2. In the teaching process, students only do some simple experiments in the laboratory, and lack a large number of comprehensive practical experiments. It is far from meeting the target which is to develop product design ability.

3. Because the laboratory equipment and tutorials are limited, the teaching still focuses on Protues software simulation.

To overcome the above three problems, project-driven teaching reform of SCM curriculum is studied. Base on the homemade SCM experiment box, the layered and progressive project groups are constructed. The project-driven teaching method is proposed. Project teaching evaluation and curriculum assessment mechanism for practical ability are reformed and improved. Finally the reform content of SCM curriculum improves the teaching efficiency, mobilizes the enthusiasm of students and lays the foundation for the promotion.

\section{Introduction of SCM Experiment Box}

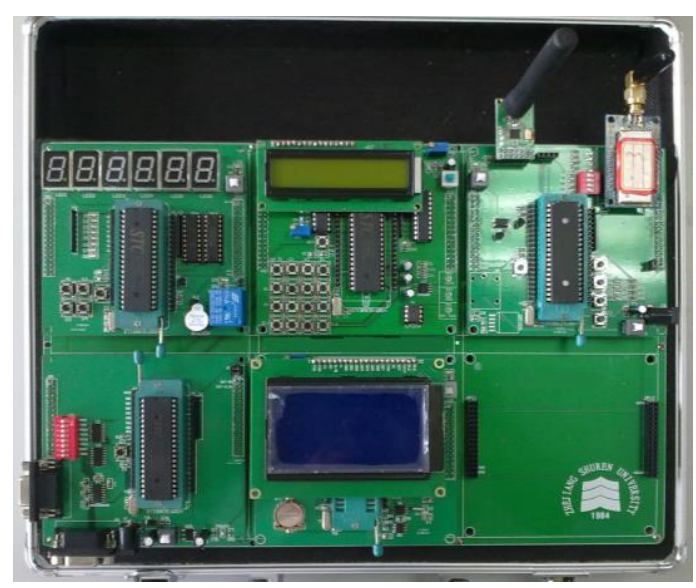

Figure. 1 Homemade SCM experiment box

The SCM experiment box based on 51 single chip microcontroller of Hongjing Technology Limited Company has been successfully developed. As shown in fig.1, basic experiment board, advanced experiment board, wireless communication comprehensive experiment board, power board and perpetual calendar comprehensive experiment board are distributed from top to bottom and from left to right in the experiment box. The power board is composed of SCM smallest system, power supply module, multiplexers, 232 module and other components. Its main function is to download program and provide power for the experiment boards. The basic experiment board is composed of SCM smallest system, seven-segment LED, latches, LED lights, relay, buzzer and other components. The board achieves the functions such as water lights, seven-segment LED display, buzzer switch and relay switch. The advanced experiment board is composed of SCM smallest system, $4 * 4$ matrix keyboards, DA conversion module AD0804, AD conversion module DA0832, 1602 display module and other components. The board achieves the functions such as 1602 display controlled by keyboards, DA conversion and $\mathrm{AD}$ conversion. The perpetual calendar comprehensive experiment board is composed of SCM smallest system, temperature sensor DS18B20, clock module DS1302, 12864 display module, external program memory $24 \mathrm{C} 00$ and other components. The board achieves the functions such as perpetual calendar and temperature display in the 12864 screen. The wireless communication comprehensive experiment board is composed of SCM smallest system, zigbee wireless communication module, NRF905 wireless communication module and other components. The board 
realizes the functions of wireless communication and control. In summary, the SCM experiment box creates the condition for the realization of project teaching in the SCM curriculum.

\section{Teaching Reform}

Based on the homemade SCM experiment box, the following three aspects are studied [7-10]. The contents are as follows.

Layered and progressive project group construction of SCM. Teaching resources in the traditional teaching mode are simple and poor interactive. They are not suitable for the project-driven teaching. Therefore, according to the difficulty degree of curriculum knowledge and the four experiment boards which are basic experiment board, advanced experiment board, perpetual calendar comprehensive experiment board and wireless communication comprehensive experiment board, the teaching content is decomposed into project groups of three levels. They are basic project group, advanced project group and comprehensive project group. In the classroom teaching, the theoretical teaching and practical project are combined closely. Everyone is equipped with an experiment box and independently design the program.

Table 1 Teaching content selection

\begin{tabular}{|c|c|c|c|c|}
\hline Project group & $\begin{array}{c}\text { Related } \\
\text { Hardware }\end{array}$ & Project Content & Related Knowledge & $\begin{array}{l}\text { Class } \\
\text { hour }\end{array}$ \\
\hline \multirow{13}{*}{$\begin{array}{l}\text { Basic project } \\
\text { group }\end{array}$} & \multirow{13}{*}{$\begin{array}{c}\text { Basic } \\
\text { experiment } \\
\text { board }\end{array}$} & (1) schematic design experiment & Protel99 software application & 2 \\
\hline & & $\begin{array}{l}\text { (2) package library design } \\
\text { experiment }\end{array}$ & Protel99 software application & 3 \\
\hline & & (3) PCB design experiment & Protel99 software application & 3 \\
\hline & & (4) hardware experiment & Circuit welds and debugs & 3 \\
\hline & & (5) I/O port application experiment & I/O port output principle & 3 \\
\hline & & (6) water light experiment & I/O port output principle & 3 \\
\hline & & (7) buzzer experiment & I/O port output principle & 3 \\
\hline & & (8) independent key experiment & I/O port input principle & 3 \\
\hline & & (9) interrupt system experiment & Interrupt system principle & 3 \\
\hline & & (10) timer and counter experiment & Timer principle & 3 \\
\hline & & (11) 7 digital tubes experiment & Digital tube principle & 3 \\
\hline & & (12) uart communication experiment & Uart principle & 3 \\
\hline & & (13) comprehensive experiment & Comprehensive knowledge & 3 \\
\hline \multirow{5}{*}{$\begin{array}{l}\text { Advanced } \\
\text { project group }\end{array}$} & \multirow{5}{*}{$\begin{array}{l}\text { Advanced } \\
\text { experiment } \\
\text { board }\end{array}$} & (14) 1602 LCD display experiment & 1602 LCD principle & 3 \\
\hline & & (15) matrix keyboard experiment & $4 * 4$ matrix input principle & 3 \\
\hline & & (16) AD conversion experiment & AD conversion principle & 3 \\
\hline & & (17) DA conversion experiment & DA conversion principle & 3 \\
\hline & & (18) comprehensive Experiment & Comprehensive knowledge & 3 \\
\hline \multirow{4}{*}{$\begin{array}{l}\text { Comprehensive } \\
\text { project group }\end{array}$} & \multirow{4}{*}{$\begin{array}{c}\text { Perpetual } \\
\text { calendar } \\
\text { comprehensive } \\
\text { experiment } \\
\text { board } \\
\end{array}$} & (19) LCD display experiment & 12864 LCD introduction & 3 \\
\hline & & (20) temperature sense experiment & DS18B20 chip introduction & 3 \\
\hline & & (21) real-time clock experiment & DS1302 chip introduction & 3 \\
\hline & & (22) comprehensive experiment & Comprehensive knowledge & 3 \\
\hline \multirow{6}{*}{$\begin{array}{l}\text { Comprehensive } \\
\text { project group }\end{array}$} & \multirow{5}{*}{$\begin{array}{c}\text { Wireless } \\
\text { communication } \\
\text { comprehensive } \\
\text { experiment } \\
\text { board }\end{array}$} & (23) RF communication experiment & NRF905 chip introduction & 3 \\
\hline & & $\begin{array}{l}\text { (24) Zigbee communication } \\
\text { experiment }\end{array}$ & Zigbee module introduction & 3 \\
\hline & & (25) temperature sense experiment & SHT11 chip introduction & 3 \\
\hline & & (26) LED light control experiment & Control circuit introduction & 3 \\
\hline & & (27) comprehensive experiment & Comprehensive knowledge & 3 \\
\hline & Total & & & 80 \\
\hline
\end{tabular}

As shown in table 1, according to the four experiment boards of different functions, teaching content is divided into four project groups. Each project group is divided into several basic 
experiments and one comprehensive experiment. The knowledge and skills involved in the basic experiments are in the required range of curriculum syllabus. Comprehensive experiment combines all knowledge points in the project group, consolidates the student knowledge, examines the mastering situation and deepens the understanding of knowledge points. In short, projects are from easy to difficult and progressive. Layered, classified and progressive project groups which guide students to progressively learn are constructed.

Project-driven teaching method. The above projects are considered, and the project-driven teaching method is used to implement teaching of SCM curriculum and play the leading role of teachers and main role of students. The method has nine steps which are project selection, project analysis, knowledge point extraction, task arrangement, knowledge point application, plan formulation, project implementation, project conclusion, thought and improvement. The steps are as follows.

(1) One appropriate experiment project is selected according to teaching progress.

(2) The experiment project is analyzed by heuristic teaching.

(3) The corresponding knowledge points are extracted. They are explained to let students have certain understanding. Students are guided by teachers to think independently, understand and digest the knowledge points by themselves.

(4) The teaching tasks are arranged.

(5) Students are encouraged to explore the solutions of problem. Namely their knowledge is applied to complete the task.

(6) The plan is formulated for the project.

(7) Students are allowed to design the program, and required to debug and verify the program in the SCM experiment box and complete the tasks.

(8) The project is concluded. The principle, program flow chart and program design are concluded in the form of courseware. The teaching focus of the project is emphasized.

(9) After-school thinking question is arranged to further consolidate the knowledge learning of students.

In short, a project-driven teaching method of SCM curriculum is proposed. The method emphasizes the student participation in teaching and guides students to learning when they do the project. It stimulates the student learning motivation and self-learning ability, and fully embodies the idea which is learning by doing and learning to do.

Project teaching evaluation and curriculum assessment mechanism. The SCM curriculum should focus on the analysis, understanding and application of the knowledge points, and practical ability assessment. Therefore, the student evaluation of the curriculum focuses on the practice ability, and pays attention to the evaluation of student learning situations in the teaching process.

$$
S_{\text {Final }}=10 \% * S_{\text {usual }}+30 \% * \sum_{m} S_{m}^{E} / M+60 \% * S_{C}
$$

Where, $S_{\text {Final }}$ represents the final score. $S_{\text {usual }}$ represents the usual score. $S_{m}^{E}$ represents the score of experiment project $m$. $M$ represents the number of projects which need to be done in the curriculum teaching. $S_{C}$ represents the score of final comprehensive project. 
Table 2 Student evaluation table of one experiment project

\begin{tabular}{|c|c|c|}
\hline Teaching objectives of the project & $\begin{array}{c}\text { Aggregate } \\
\text { Score (100) }\end{array}$ & $\begin{array}{c}\text { The } \\
\text { Score }\end{array}$ \\
\hline Does student understand the basic principle of knowledge points? & 10 & 8 \\
\hline Can student use the KeilC51 software to design the project program? & 25 & 20 \\
\hline Can student debug and modify the program when function changes? & 20 & 20 \\
\hline $\begin{array}{c}\text { The writing situation of experiment report (Emphasize the program } \\
\text { flow chart, circuit diagram and experience) }\end{array}$ & 45 & 35 \\
\hline Final score & 100 & 83 \\
\hline
\end{tabular}

Table 3 Student evaluation table of final comprehensive project

\begin{tabular}{|c|c|c|c|c|c|}
\hline $\begin{array}{c}\text { Content } \\
\text { Weight }\end{array}$ & $\begin{array}{c}\text { Hardware } \\
\text { Score }(20 \%)\end{array}$ & $\begin{array}{c}\text { Software Score } \\
(20 \%)\end{array}$ & $\begin{array}{c}\text { Design Report } \\
\text { Score }(40 \%)\end{array}$ & $\begin{array}{c}\text { PPT Report } \\
\text { Score }(20 \%)\end{array}$ & $\begin{array}{c}\text { Comprehensive } \\
\text { Project Score }\end{array}$ \\
\hline Student & 80 & 90 & 85 & 90 & 86 \\
\hline
\end{tabular}

As shown in Eq.1, the student learning evaluation is divided into three parts. The first part is usual performance which is evaluated according to the student class attendance, class status and homework situation assessment. It accounts for $10 \%$ of the final score. The second part is the implementation assessment of all experiment projects in the full term. It accounts for 30\% of the final score. As shown in table 2, the student score of each experiment project is evaluated according to the student mastery situation of knowledge points, completion situation of tasks, design results and writing situation of experiment report. The third part is the performance in the final comprehensive project design. It accounts for $60 \%$ of the final score. Final comprehensive project design is that each student uses the hardware resource of SCM experiment box and knowledge points involved in the class, chooses a comprehensive project from the title library, and uses inside and outside class time to achieve the desired task. Each student also needs to submit the comprehensive project's hardware, program and research report, and report the design result in the form of courseware to other students. As shown in table 3, teachers give the score of final comprehensive project for each student according to the design results and weights. Finally, the final score of the SCM curriculum for each student is obtained.

\section{Conclusion}

The project-driven teaching reform of SCM curriculum is studied. Based on the homemade SCM experiment box, the teaching reform is proposed. It develops SCM application talents, contacts actual daily life, weakens SCM theoretical knowledge, and integrates theoretical knowledge into each application experiment. Students not only learn new theoretical knowledge, but also solve some problems in the real life when they do the project. Meanwhile, the reform improves teaching quality of SCM curriculum. After further improvement, the reform is applicable to other application-oriented curriculums, and has some reference value.

\section{Acknowledgments}

This study was supported by Zhejiang shuren university reform project of China under grant 2014JA1006, Zhejiang provincial education research planning project of China under grant JB039, and laboratory work research project (study on SCM remote experiment teaching platform based on project drive) of Zhejiang province higher education institute.

\section{References}

[1] Ministry of education of the people's republic of china, Long-term education reform and development planning framework (2010-2020), 
http://www.moe.edu.cn/publicfiles/business/htmlfiles/moe/moe_838/201008/93704.html, 2010-07-29.

[2] People's government of the people's republic of china, Long-term talent development planning framework (2010-2020), http://www.gov.cn/jrzg/2010-06/06/content_1621777.htm, 2010-06-06.

[3] S.Q. Chen, Analysis on the experiment teaching of single chip microcomputer, Journal of Xichang College (Natural Science Edition), 4 (2012) 62-64.

[4] C.L. Liu, C.B. Huo, T. C. Wang, Reform and practice of project driven teaching method in "SCM principle and application" of non electrical majors, Journal of Liaoning University of Technology (Social Science Edition). 5 (2014) 135-137.

[5] B. Li, Teaching reform and practice by project of MCU course, Laboratory Science. 1 (2014) 101-103.

[6] J.P. Hu, C. Wang, Research and practice of SCU project teaching method, Journal of EEE. 5 (2009) 82-84.

[7] L.J. Zhong, J.J. Zhao, W.H. Dai, X.Q. Dai, Practice teaching reform about project introduction and task driven (taking SCM teaching as an example). Journal of Hubei University of Science and Technology. 11 (2013) 138-139.

[8] Y. Ruan, Y. Tang, Z.Q. Wang, Construction of MCU Project group from the systematic perspective in practice teaching, Journal of Zhejiang Shuren University. 2 (2013) 56-59.

[9] J.L. Wang, X.M. Zheng, J. Hu, Application of project-driven method in MCU comprehensive experiment, Journal of Ningbo University of technology. 3 (2012) 88-90.

[10] T. Li, D.W. Xiao, L.Q. Jiang, Research on the teaching mode of SCM practice based on project-oriented, Science and Technology Innovation Herald. 5 (2014) 7-8. 